\title{
RESPON BARAT TERHADAP ISLAM \\ SEBAGAI SUMBER PERADABAN
}

\section{Abstrak}

\author{
Oleh : Wasito
}

Islam adalah agama abrahamik yang pada perjalanan kemudian menjelma menjadi peradaban besar. Bahkan, pada kurun waktu sebelum abad ke $13 \mathrm{M}$ atau tepatnya sebelum masa renaissance di Barat, peradaban Islam menjadi pemimpin dan kiblat peradaban-peradaban dunia.

Meski demikian, kendati diakui atau tidak Barat berhutang budi pada Islam untuk kemajuan peradabannya sebagaimana sekarang ini, tidak sedikit orang-orang Barat yang mengakuinya. Dengan kata lain, respon Barat atas Islam sebagai sumber peradaban tidak ijmal, namun terpecah menjadi dua, yaitu respon positif dan respon negatif.

Key Words: Respon Barat, Islam, Sumber Peradaban

\section{Pendahuluan}

Agama Islam adalah agama yang sya>mil dan $\mathrm{ka}>$ mil. Artinya, sempurna dan menyeluruh sebagai rahmat bagi seluruh ummat manusia. Derajat kesempurnaan agama ini tidak dapat diruntuhkan oleh berbagai pendapat. Beberapa kalangan yang mencoba mengobok-obok Islam, terkena batunya sendiri. Kesempurnaan Agama Islam bukan hanya terletak pada aspek ibadah dan kepercayaan. Lebih daripada itu, Islam memiliki syari'at bagi ummatnya yang menjadi pedoman kebahagiaan di dunia dan akhirat. Syari'at inilah pokok beradabnya suatu bangsa. Tanpa syari'at/ peraturan, manusia tidak lebih dari binatang yang saling memusuhi satu sama lainya, walau berakal.

Dalam syari'ah Islam, seorang disuruh untuk melakukan kebaikan dan menjauhkan diri dari kemungkaran. Mewajibkan kepada ummatnya untuk menjaga kebersihan, menepati janji, berkata jujur, tidak mengkhianati amanah dan masih banyak lagi perintah dalam syari'at Islam yang mengarahkan manusia untuk membentuk sebuah peradaban. 
Maka, tak ayal sumber utama peradaban ummat Islam terletak pada dua pusaka yang ditinggalkan Nabi akhir zaman, Muhammad SAW. Kedua pusaka itu adalah Al-Qur'an dan Assunnah. Membaca dan mengamalkan kedua pusaka tersebut, maka seseorang tidak akan tersesat baik di dunia maupun akhirat. Dalam kata lain, sudah mendapatkan jaminan kebahagiaan selamanya.

Namun disini kami berusaha kembali mengkaji bagaimanakah filosofi sejarah dan peradaban Islam yang akan membahas tentang Islam sebagai sumber Peradaban dan Bagaimana respon Barat terhadap Islam

\section{Islam Sebagai Sebuah Peradaban}

Tanda wujudnya peradaban, menurut Ibnu Khaldun adalah berkembangnya ilmu pengetahuan seperti fisika, kimia, geometri, aritmetik, astronomi, optik, kedokteran Bahkan maju mundurnya suatu peradaban tergantung atau berkaitan dengan maju mundurnya ilmu pengetahuan. Jadi substansi peradaban yang terpenting dalam teori Ibnu Khaldun adalah ilmu pengetahuan. Namun ilmu pengetahuan tidak mungkin hidup tanpa adanya komunitas yang aktif mengembangkannya. Karena itu suatu peradaban atau suatu umran harus dimulai dari suatu "komunitas kecil" dan ketika komunitas itu membesar maka akan lahir umran besar. Komunitas itu biasanya muncul di perkotaan atau bahkan membentuk suatu kota. Dari kota itulah akan terbentuk masyarakat yang memiliki berbagai kegiatan kehidupan yang timbul dari suatu sistem kemasyarakatan dan akhirnya lahirlah suatu Negara. Kota Madinah, kota Cordova, kota Baghdad, kota Samara, kota Kairo dan lain-lain adalah sedikit contoh dari kota yang berasal dari komunitas yang kemudian melahirkan Negara. Tanda-tanda lahir dan hidupnya suatu umran bagi Ibnu Khaldun di antaranya adalah berkembanganya teknologi, (tekstil, pangan, dan papan / arsitektur), kegiatan eknomi, tumbuhnya praktek kedokteran, kesenian (kaligrafi, musik, sastra dsb). Di balik tanda-tanda lahirnya suatu peradaban itu terdapat komunitas yang aktif dan kreatif menghasilkan ilmu pengetahuan.

Namun di balik faktor aktivitas dan kreativitas masyarakat masih terdapat faktor lain yaitu agama, spiritualitas atau 
kepercayaan. Para sarjana Muslim kontemporer umumnya menerima pendapat bahwa agama adalah asas peradaban, menolak agama adalah kebiadaban. Sayyid Qutb menyatakan bahwa keimanan adalah sumber peradaban. Meskipun dalam peradaban Islam struktur organisasi dan bentuknya secara material berbeda-beda, namun prinsip-prinsip dan nilai-nilai asasinya adalah satu dan permanent. Prinsip-prinsip itu adalah ketaqwaan kepada Tuhan (taqwa), keyakinan kepada keesaan Tuhan (tauhid), supremasi kemanusiaan di atas segala sesuatu yang bersifat material, pengembangan nilai-nilai kemanusiaan dan penjagaan dari keinginan hewani, penghormatan terhadap keluarga, menyadari fungsinya sebagai khalifah Allah di Bumi berdasarkan petunjuk dan perintah-Nya (syariat).

Sejalan dengan Sayyid Qutb, Syeikh Muhammad Abduh menekankan bahwa agama atau keyakinan adalah asas segala peradaban. Bangsa-bangsa purbakala seperti Yunani, Mesir, India, dll, membangun peradaban mereka dari sebuah agama, keyakinan atau kepercayaan. Arnold Toynbee juga mengakui bahwa kekuatan spiritual (batiniyah) adalah kekuatan yang memungkinkan seseorang melahirkan manifestasi lahiriyah (outward manifestation) yang kemudian disebut sebagai peradaban itu.

Jika agama atau kepercayaan merupakan asas peradaban, dan jika agama serta kepercayaan itu membentuk cara pandang seseorang terhadap sesuatu yang pada gilirannya dapat mempengaruhi tindakan nyatanya atau manifestasi lahiriyahnya, maka sejalan dengan teori modern bahwa pandangan hidup (worldview) merupakan asas bagi setiap peradaban dunia. Jika makna worldview adalah konsep nilai, motor bagi perubahan sosial, asas bagi pemahaman realitas dan asas bagi aktivitas ilmiah, maka Islam mengandung itu semua. Islam bahkan memiliki pandangan terhadap realitas fisik dan non fisik secara integral. Ayat-ayat al-Qur'an jelas-jelas adalah konsep seminal yang memproyeksikan pandangan Islam tentang alam semesta dan kehidupan yang disebut pandangan hidup atau pandangan alam Islam (worldview, al-tat\}awwur al-Isla $>$ mi $>$, al-mabda alIsla $>m i>$ ) itu. Bukan hanya itu, konsep-konsep itu diberi medium pelaksanaannya yang berupa institusi yang disebut din, yang di dalamnya terkandung konsep peradaban (Tamadd $u>n$ ). 
Menurut Ibnu Khaldun, wujud suatu peradaban merupakan produk dari akumulasi tiga elemen penting yaitu :

1. Kemampuan manusia untuk berfikir yang menghasilkan sains dan teknologi.

2. Kemampuan berorganisasi dalam bentuk kekuatan politik dan militer.

3. Kesanggupan berjuang untuk hidup. Jadi kemampuan berfikir merupakan elemen asas suatu peradaban.

Suatu bangsa akan beradab (berbudaya) hanya jika bangsa itu telah mencapai tingkat kemampuan intelektual tertentu. Sebab kesempurnaan manusia ditentukan oleh ketinggian pemikirannya. Suatu peradaban hanya akan wujud jika manusia di dalamnya memiliki pemikiran yang tinggi sehingga mampu meningkatkan taraf kehidupannya. Suatu pemikiran tidak dapat tumbuh begitu saja tanpa sarana dan prasarana ataupun suprastruktur dan infra-struktur yang tersedia. Dalam hal ini pendidikan merupakan sarana penting bagi tumbuhnya pemikiran, namun yang lebih mendasar lagi dari pemikiran adalah struktur ilmu pengetahuan yang berasal dari pandangan hidup. Untuk menjelaskan bagaimana pemikiran dalam peradaban Islam merupakan faktor terpenting bagi tumbuh berkembangnya peradaban Islam, kita rujuk tradisi intelektual Islam.

\section{Islam dan Barat}

Adanya pengetahuan akan sangat bermanfaat guna membantu meningkatkan pemahaman antara Islam dan Barat. Konfrontasi adalah sesuatu yang tidak perlu dan tidak diinginkan, karena ada banyak persamaan diantara dua peradaban dalam pemikiran maupun dalam realitas kehidupan kemasyarakatan. Banyak perbedaan yang bersifat dangkal, sedangkan nilai - nilai yang lebih dalam dan lebih permanen lebih memiliki banyak persamaan: Penghargaan terhadap pengetahuan, keadilan, rasa simpati terhadap orang yang kehilangan hak-haknya, dan lain sebagainya.

Meskipun ada suatu hasrat yang sungguh-sunguh dari barat untuk memahami Islam, orang-orang di sana mempunyai suatu masalah dalam memahaminya, mungkin karena 
pengalaman -pengalaman saling bermusuhan dalam sejarah sebelum-sebelumnya. Image-image dan ide-ide yang keliru kemudian diabaikan. Sebagai contoh, ada suatu artikel tentang keyakinan yang hampir tak tergoncangkan dalam dunia Barat bahwa umat muslim memperlakukan wanita-wanita dengan buruk dan bahwa pemimpin-pemimpin upacara keagamaan muslim dalam bentuk mullah menjadi tiran dalam masyarakat múslim.

Umat Islam mengeluh telah dijajah oleh barat dua kali: secara politik dalam abad sebelumnya dan kemudian secara budaya dalam abad ini .Tapi Eropa juga mempunyai kenangannya sendiri tentang penaklukan Islam dalam abad-abad pertama setelah Islam muncul. Spanyol dan sisilia berada dibawah dominasi muslim selama berabad-abad, dan pasukan muslim dihentikan menaklukan perancis oleh Charles Martel pada abad ke 18 vienna hamper ditaklukan dua kali,usaha yang kedua dilakukan pada abad ke 17.

Konfrontasi antara Islam dan barat secara luas dilihat di dunia Muslim sebagai suatu benturan yang terus menerus, antara keserakahan dan keimanan, antara suatu cara hidup yang mendorong kekerasan dan anarki dengan hidup yang menekankan keseimbangan dan ketertiban. Namun image-image ini sama sekali terbalik dalam pandangan barat.

\section{Respon Barat atas Peradaban Islam}

Terdapat dua pandangan atau respon Barat, melihat kemajuan peradaban Islam, yaitu positif dan negatif. Respon positif, salah satunya, mereka tunjukkan dengan keikutsertaan mereka mengadakan pembelajaran terhadap ilmu pengetahuan Islam. Mereka menganggap Islam telah memberikan konstribusi besar terhadap peradabannya yang semakin maju. Sedangkan negatifnya, bentuknya lebih mereka arahkan dengan memberikan pemikiran-pemikiran yang substansinya adalah kritikan dan argumen-argumen yang menjatuhkan Islam dalam berbagai aspek kehidupan. Mereka memandang umat Islam 
sebagai sumber kekerasan dan anarki yang mengancam barat yang mapan dan makmur. ${ }^{1}$

Respon pertama, kemajuan eropa yang terus berkembang hingga saat ini banyak berhutang budi kepada khazanah ilmu pengetahuan Islam yang berkembang di periode klasik. Terdapat banyak saluran bagaimana peradaban Islam mempengaruhi Eropa ,seperti Spanyol, Sicillia dan perang salib Tetapi saluran yang penting adalah spanyol Islam.

Dari ketiga saluran tersebut Spanyol merupakan tempat yang paling utama bagi Eropa yang menyerap peradaban Islam, baik dalam bentuk hubungan politik ,sosial maupun perekonomian ,dan peradaban antar Negara. Orang-orang Eropa menyaksikan kenyataan bahwa Spanyol berada di bawah kekuasaan Islam jauh meninggalkan Negara-negara tetangganya Eropa, terutama dalam bidang pemikiran dan sains dan bangunan fisik, hingga di Eropa timbul gerakan Averroeisme (ibnu-rusyd-isme) yang menuntut kebebasan berpikir. Berawal dari gerakan Averroeisme inilah kemudian Eropa meresponnya dengan mengadakan atau melahirkan reformasi pada abad ke-16 $\mathrm{M}$ dan rasinolisme pada abad ke-17 M . Buku-buku Ibnu Rusyd dicetak di vinesia tahun 1481,1482,1483,1489.dan $1500 \mathrm{M}$. Timbulnya gerakan ini berawal dari banyaknya pemuda-pemuda Kristen Eropa yang belajar di universitas-universitas Islam di Spanyol. Selama belajar, mereka aktif menerjemahkan bukubuku karya ilmuwan-ilmuwan muslim. Setelah pulang ke negerinya, mereka mendirikan sekolah dan universitas yang sama. Sehingga Eropa mendapatkan kembali peradaban yang lebih maju ${ }^{2}$.

Pengaruh ilmu pengetahuan Islam atas Eropa yang sudah berlangsung abad ke $12 \mathrm{M}$ itu menimbulkan gerakan kebangkitan kembali (renaissance) pusaka Yunani dan Eropa pada abad ke 14 M. Berkembangnya Yunani di Eropa kali ini melalui terjemahan-terjemahan Arab yang dipelajari dan kemudian diterjemahkan kembali ke dalam bahasa Latin.

\footnotetext{
${ }^{1}$ Akbar S. Ahmed, Rekonstruksi Sejarah Islam,terj.Amru Nst (Yogyakarta: Fajar Pusaka Baru,2003), h.4-6.

${ }^{2}$ Badri Yatim, Sejarah Peradaban Islam (Jakarta: PT.Rajagrafindo Persada,2008), h.109
} 
Hingga peradaban Islam telah memberi kontribusi besar dalam berbagai bidang khususnya bagi dunia Barat yang saat ini diyakini sebagai pusat peradaban dunia. Kontribusi besar tersebut antara lain :

1. Sepanjang abad ke-12 dan sebagian abad ke-13, karya-karya kaum Muslim dalam bidang filsafat, sains, dan sebagainya telah diterjemahkan ke dalam bahasa Latin, khususnya dari Spanyol. Penerjemahan ini sungguh telah memperkaya kurikulum pendidikan dunia Barat.

2. Kaum muslimin telah memberi sumbangan eksperimental mengenai metode dan teori sains ke dunia Barat.

3. Sistem notasi dan desimal Arab dalam waktu yang sama telah dikenalkan ke dunia barat.

4. Karya-karya dalam bentuk terjemahan, kususnya karya Ibnu Sina (Avicenna) dalam bidang kedokteran, digunakan sebagai teks di lembaga pendidikan tinggi sampai pertengahan abad ke-17 M.

5. Para ilmuwan muslim dengan berbagai karyanya telah merangsang kebangkitan Eropa, memperkaya dengan kebudayaan Romawi kuno serta literatur klasik yang pada gilirannya melahirkan Renaisance.

6. Lembaga-lembaga pendidikan Islam yang telah didirikan jauh sebelum Eropa bangkit dalam bentuk ratusan madrasah adalah pendahulu universitas yang ada di Eropa.

7. Para ilmuwan muslim berhasil melestarikan pemikiran dan tradisi ilmiah Romawi-Persi (Greco Helenistic) sewaktu Eropa dalam kegelapan.

8. Sarjana-sarjana Eropa belajar di berbagai lembaga pendidikan tinggi Islam dan mentransfer ilmu pengetahuan ke dunia Barat.

9. Para ilmuwan Muslim telah menyumbangkan pengetahuan tentang rumah sakit, sanitasi, dan makanan kepada Eropa. ${ }^{3}$

Pada kondisi-kondisi tersebut, terutama pada abad ke-11 dan ke-12, walaupun tradisi Islam yang diboyong ke Barat

3 Mehdi Nakosteen, Kontribusi Islam Atas Dunia Intelektual Barat, Deskripsi Analisis Abad Keemasan Islam, terj. Joko S. Kahhar dan Supriyanto Abdullah, cet. 2, (Surabaya : Risalah Gusti, 2003) h. 85. 
masih belum terjadi pemisahan yang jelas antara ilmu-ilmu yang ada dan ketika itu ilmu kalam, filsafat, tasawuf, ilmu alam, matematika, dan ilmu kedokteran masih bercampur. Akan tetapi Islam telah mampu mendamaikan akal dengan iman dan filsafat dengan agama. Sedangkan bangsa Barat pada masa itu masih terdapat stereotipe yang memisahkan antara akal dan iman serta filsafat dan agama. Hal ini juga terjadi pada ilmu pengetahuan dan ilmu alam, yang mana Islam telah berjasa menyatukan akal dengan alam, menetapkan kemandirian akal, menetapkan keberadaan hukum alam yang pasti, dan keserasian Tuhan dengan alam.

Hingga akhirnya filsafat skolastik Barat mencapai puncaknya yang telah didukung oleh adanya pilar Islam dengan dibangunnya akademi-akademi di Eropa yang diadopsi dari gaya akademi di kawasan Timur. Hal ini merupakan evolusi dari illuminisme biara ke kegiatan pemikiran yang dialihkan ke sekolahan dan akademi. Dan kurikulum yang diajarkan adalah filsafat lama, dan ilmu-ilmu Islam terutama Averoisme Paris. Pada saat yang sama terjadi perubahan kecenderungan pemikiran dari kesenian dan kasusatraan ke gramatika dan logika, dari retorika ke filsafat dan pemikiran, dan dari paganisme kesusastraan Latin ke penyucian Tuhan sebagai pemikiran Islam.

Demikianlah sumbangan besar Islam atas peradaban dunia Barat, yang selanjutnya jusru dijadikan sebagai pusat peradaban dunia pada saat ini. Hal ini dikarenakan kekonsistensian dunia Barat dalam mengembangkan ilmu pengetahuan dan teknologinya. Bahkan karya-karya besar para ilmuwan Muslim tersebut hingga kini masih dapat kita teukan di perpustakaanperpustakaan internasional, khususnya di Amerika, yang secara profesional dan rapi telah menyimpannya. ${ }^{4}$ Sehingga para umat Muslim di masa kini, yang ingin mempelajari lebih banyak tentang khasanah Islam tersebut, harus pergi ke negara Barat (non Islam) agar dapat meminta kembali "permata" sementara ini telah mereka pinjam.

\footnotetext{
4 Abdurrahman Mas'ud, Islam dan Peradaban (sebagai pengantar), dalam Samsul Munir Amin, h. x.
} 
Respon kedua, bentuk dari respon kedua ini adalah penjajahan. Ini berawal dari rasa iri Eropa yang mersa ketinggalan jauh dari Islam. seratus tahun setelah wafatnya nabi Muhammad Saw., para khalifah penggantinya mampu mendirikan kerajaan Abbasyiyah yang kuat dan lebih besar dari kerajaan Byzantium, Roma Timur ${ }^{5}$. Mengetahui keadaan tersebut, kerajaan Kristen Roma merasa khawatir kalau akhirnya kekuatan mereka tertandingi oleh Islam-Arab. Kekhawatiran itu akhirnya menjadi kenyataan. Pada abad ke-7 dan ke-8 umat Islam Arab bersatu dan melakukan penakhlukan terhadap kerajaan Byzantium, dan pada abad itu pula terbentanglah wilayah kekhalifahan Islam hingga Hindia ${ }^{6}$. Karena penakhlukan tersebut kerajaan Byzantium mengalami krisis. Penakhlukan dan ekspansi yang dilakukan kekhalifahan Islam semakin meluas. Pada abad ke-8 Prancis Tengah dan Italia pun dapat dikuasai ${ }^{7}$. Keadaan ini membuat Kristen Eropa semakin marah dan menaruh dendam sangat besar terhadap kekutan Islam yang dianggap telah menghancurkan Kristen terutama dalam bidang politik dan agama. Tetapi rasa kebencian itu mereka sembunyikan.

Hearnsaw pernah berkata bahwa saat pertama kali eropa melancarka serangan terhadap umat Islam pada perang salib, Eropa terkejut dengan peradaban yang dimiliki oleh umat Islam pada saat itu ${ }^{8}$. Peradaban Islam ternyata lebih maju daripada peradaban Eropa. Dari sinilah Eropa menyerap ilmu penetahuan dan teknologi dari ilmuwan muslim. Eropa berhutang budi kepada Islam. Kemajuan yang telah Eropa peroleh tidak terlepas dari kontribusi khazanah peradaban Islam.

Setelah munculnya renaissance yang berlangsung pada abad ke-14 hingga abad ke-15, eropa mengalami kemajuan yang sangat pesat sehingga meninggalkan Islam yang pada saat itu mengalami kemunduran peradaban. Eropa mulai banyak

${ }^{5}$ John L. Esposito, Ancaman Islam: Mitos atau Realitas, terj. Alwiyah Abdurrahman dan MISSI, cet.3, ed.rev, (Bandung: Mizan,1996), h.41

${ }^{6}$ Ibid., h. 41-42.

${ }^{7}$ Badri Yatim, Sejarah Peradaban Islam, cet. Ke-12, (Jakarta: PT. Rajagrafindo Persada, 2001), h.90-91.

${ }^{8}$ Ahmad Syalabi, Sejarah dan Kebudayaan Islam, terj. Muhammad Labib Ahmad, cet. Ke-9, (Jakarta: PT. Al Husna Zikr,1997), h.204. 
melakukan inovasi-inovasi penting dalam bidang teknologi dari pengembangan ilmu

\section{Kesimpulan} berikut:

Uraian - uraian di atas dapat ditarik kesimpulan sebagai

1) Makkah menjadi kota suci bagi Nabi Muhammad dan umatnya Peradaban Islam melalui beberapa periode, yaitu: a).Zaman Rosulullah dan khulafa'urrasyidin, b). Zaman dinasti Umayyah, c). Zaman dinasti Abbasiyah, d). Zaman dinasti Turki.

2) Banyak persamaan di antara dua peradaban: peradaban Islam dan peradaban Barat, baik dalam hal pemikiran maupun dalam realitas kemasyarakatan. Namun dalam kenyataanya, mereka lebih terjebak dalam konfrontasi yang tiada ujungnya. Hal ini dikarenakan pengalaman-pengalaman terdahulu yang saling bẻmusuhan.

3) Mengenai respon Barat terhadap Islam, terdapat dua respon yaitu positif dan negatif. Salah satu respon positifnya mereka tunjukan dengan mengadakan pembelajaran terhadap ilmu pengetahuan Islam. Mereka lebih berfikir positif, menganggap Islam telah memberikan konstribusi besar terhadap peradaban dunia. Sedang respon negatifnya lebih mengarah kepada tujuan untuk menjatuhkan dan ingin menguasai Islam. 


\section{Daftar Pustaka}

Chamid, Nur. Jejak Langkah Sejarah Pemikiran Ekonomi Islam. Yogyakarta: Pustaka Pelajar. 2010.

Esposito, John L., Ancaman Islam:mitos atau realitas, terj. Alwiyah Abdurrahman dan MISSI, Bandung: Mizan,1996.

Nasution, Harun. Islam Ditinjau Dari Berbagai Aspeknya. Jilid I. Jakarta: UI-Press. 1986.

Syalabi, Ahmad. Sejarah dan Kebudayaan Islam. Jilid I. terjemahan Muchtar Yahya dan Sanusi Latif. Jakarta: Pustaka Al-Husna. 1998.

Sou'yf, Joesuef. Sejarah Dalat Umaiyyah II Di Cordova. Jakarta: Bulan Bintang. 1977.

Yatim , Badri. Sejarah Peradaban Islam. Jakarta: PT Raja Grafindo. 2006.

Wahid, N Abas. Sejarah kebudayaan Islam. Surakarta : PT Tiga Serangkai Pustaka Mandiri. 2009.

Watt, W Montgomery. Kejayaan Islam: Kajian Kritis Dari Tokoh Orientalis. Yogyakarta: Tiara Wacana Yogya. 1990. 